\title{
DOES SEED TRAIT VARIABILITY SUPPORT PRELIMINARY SEED TRANSFER ZONES FOR HUNGARY?
}

\author{
Cevallos, D. $.^{1,2^{*}}-$ SzITAR, K. ${ }^{2,3}$ - HAlAssy, M. ${ }^{2}$ - KÖVEndI-JAKÓ, A. ${ }^{2}-$ TÖRÖK, K. ${ }^{2}$ \\ ${ }^{1}$ Department of Plant Systematics, Ecology and Theoretical Biology, Eötvös Loránd University, \\ Pázmány P. stny. 1/C, 1117 Budapest, Hungary \\ (phone: 06-1-381-2187; fax: +36-1-381-2188)
}

${ }^{2}$ Restoration Ecology Research Group, Centre for Ecological Research, Institute of Ecology and Botany, Alkotmány u. 2-4, 2163 Vácrátót, Hungary

(phone: +36-28-360-122; fax: +36-28-360-110)

${ }^{3}$ Lendület Landscape and Conservation Ecology Research Group, Centre for Ecological

Research, Institute of Ecology and Botany, Alkotmány u. 2-4, 2163 Vácrátót, Hungary

(phone: +36-28-360-122; fax: +36-28-360-110)

${ }^{*}$ Corresponding author

e-mail: davidcevallosg@gmail.com; phone: +36-20-434-0774

(Received 29 $9^{\text {th }}$ May 2021; accepted $23^{\text {rd }}$ Aug 2021)

\begin{abstract}
Maladaptation of populations can lead to a failed restoration when seeds are transferred to non-local target sites. Seed transfer zones (STZs) can guide transfer for restoration practices. In a previous study, we delineated STZs for Hungary based on biogeographic maps and potential natural vegetation models. The present aims were to compare the STZ with the pattern of seed trait variability of sand grasslands species (Festuca vaginata, Stipa borysthenica, Dianthus serotinus and Centaurea arenaria) from 34 localities. We assessed the effect of location as well as geographical, ecological, and environmental distances between locations on seed mass, germination, and emergence in a common garden. We detected that seed trait differentiation between the populations is a signal of local adaptation or phenotypic plasticity. Geographical distance did not affect the variability of seed traits, except on the emergence of $C$. arenaria. Ecological distance reflected in STZ delineation also did not explain seed trait variability except for the seed mass of $C$. arenaria. Aridity had a significant effect on the germination or emergence of the two forbs, but not on the grasses. In conclusion, we do not suggest restricting seed transfer among the populations over the sampled area. Further studies might complement these findings and lead to more general conclusions.
\end{abstract}

Keywords: aridity, germination, ecological distance, local provenance, thousand seed weight

\section{Introduction}

Grasslands are an important target of restoration due to their biodiversity and ecosystem services (Török and Dengler, 2018). In Europe, grasslands are jeopardized primarily by habitat fragmentation and degradation, climate change, invasive species, intensification of land use, and the abandonment of management at secondary grasslands (EC, 2008). Grassland restoration is used to mitigate the impact of degradation and fragmentation, restoring the structure, function and dynamics of the communities (Kiehl et al., 2014). Sowing seeds is a widely used method regarding species introduction for grassland restoration (Kiehl et al., 2010; Török et al., 2011; Kövendi-Jakó et al., 2019). Large seed quantities are needed for large-scale restoration projects (Merritt and Dixon, 2011; Lengyel et al., 2012) to respond to the spatial extent of degradation.

The use of seeds from local provenance is frequently suggested to avoid maladaptation (Broadhurst et al., 2008; Breed et al., 2018). A meta-analysis revealed that local species 
with large distributions and population sizes perform better than foreign plants in $71 \%$ of studies (Leimu and Fischer, 2008). The concept of "local" is rarely defined in papers; the best approach for the definition would be to rely on genetic information (McKay et al., 2005; Breed et al., 2018). However, genetic data is available only for very few species used in restoration (Bucharova et al., 2017). Therefore, the main constraint in selecting the most suitable provenance is the missing evidence of genetic differentiation for most native species.

In case of limited genetic information, the guidance of seed movement for restoration is suggested to be based on general seed transfer zones (STZs) that are geographically distinct areas within which seeds can be moved with little or no negative fitness consequences (Mijnsbrugge et al., 2010; Bower et al., 2014; Bucharova et al., 2019). STZs delimit areas with a particular set of environmental variables within which plant species are probably similarly adapted to the abiotic conditions (Bower et al., 2014). General STZs are usually recommended for multiple species (Durka et al., 2017). Studies that detect and test STZs usually select widespread generalist species that are not limited to a particular community (Bucharova et al., 2017; Durka et al., 2017). However, these species might demonstrate limited local adaptation (Reiker et al., 2015), and their use can miss the detection of zones.

The probability of gene flow among populations is assumed to decrease with geographical distance (Leimu and Fischer, 2008; Bucharova et al., 2019), as a result, genetic differentiation can occur with increasing distance (Baruch et al., 2004). However, it was also found that ecological distance (ecological differences between habitats) can better predict local adaptation than geographical distance (Herrera et al., 2002; Raabová et al., 2007). Phenotypic fitness traits (e.g. plant height, leaf length, inflorescence length) are significantly influenced by altitude, growing season, latitude, temperature and other environmental parameters and drivers of genetic differentiation (Miller et al., 2011; St. Clair et al., 2013).

Several studies have shown the relevance of eco-regions or biogeographical zones mirror species adaptive trait variabilities (Bower et al., 2014; Gibson and Nelson, 2017). Understanding the scale of local adaptation will help to define regions from which plants can be transported without detrimental effects on population fitness (Hufford and Mazer, 2003).

Experiments that compare species performance from different locations can substitute genetic analyses by sampling fitness traits, but these are also missing for most of the herbaceous species (Bucharova et al., 2017). The comparison of performance is generally done in common garden experiments, where different provenances are grown in a standard environment (Leger and Rice, 2007; Gibson et al., 2016; Germino et al., 2019). The climate of sites of population origin is generally a strong predictor of common garden performance of populations (Macel et al., 2007; Bischoff and Müller-Schärer, 2010).

The study of traits of early life stages at the seed and germination stages, may indicate adaptive differentiation (Postma and Ågren, 2016). Moreover, Raabová and colleagues (2007) found more evidence for local adaptation in seedlings than adults. Breen and Richards (2008) found that seed size was the most important factor in determining germination, survival and growth of a shrub. This connection was valid for a grass species, as well (Elgabra et al., 2019). Although seed mass is shown to demonstrate low plasticity (Hernández et al., 2019), some differences were observed in seed mass as a result of irrigation in experimental settings (Drenovsky and Richards, 2005; Breen and Richards, 2008). Germination is the earliest trait expressed by plants under strong natural 
selection before they can express other adaptive traits in later life stages, so it greatly contributes to local adaptation (Donohue et al., 2010; Cochrane et al., 2015).

Early life traits are also influenced by the parent environment during seed development, with aridity as an important driver (Elgabra et al., 2019). Drought tolerance can be locally adapted, therefore, non-adapted propagule introduction may induce reduced assimilation and resistance to pathogens, resulting in increased mortality (McDowell et al., 2008). Communities and species with higher drought tolerance might also gain importance in restoration in the future (Fry et al., 2018). Soil properties also have a great influence on the local adaptation of plants (Gibson et al., 2019). Especially the water holding capacity of soils and organic matter are related to trait variation (Johnson et al., 2010). Seed traits could thus be good indicators to identify provenances for seed transfer during restoration, but there are not enough published studies to conclude the differentiation of seed traits along abiotic gradients (Cochrane et al., 2015).

Pannonian sand grasslands are endangered habitat types of European Union conservation importance listed in the Habitats Directive (EC, 2013). Sand grasslands are edaphic communities adapted to drought that might gain further importance in restoration due to predicted future climate change with more frequent drought events. If the abandonment of cultivation occurs in sandy areas due to low profitability and frequent droughts, there is a high potential to turn these areas into native sand grasslands (Biró et al., 2013).

In our previous work, we analyzed the current situation in Hungary regarding seed transfer and delineated STZs based on the best available knowledge, combining biogeographic maps and potential natural vegetation models (Cevallos et al., 2020). In the present study, we assessed how the seed trait variability of two grass and two forb species from Pannonian sandy grasslands matches the delineated STZs, and geographical and environmental distance (based on site aridity) of their source location. For this reason, we collected seeds of the four species from altogether 34 locations in six STZ zones in Hungary and measured seed mass, germination in growth chamber and emergence in a common garden.

We conducted the research to respond to the following questions: a) Do seed traits differ according to provenance (location)? b) Do geographical and ecological (STZ) distances explain seed trait differences between locations? c) Do the site conditions defined as aridity, explain seed trait differences between locations?

\section{Materials and Methods}

\section{Study region}

The study was carried out within the Pannonian biogeographic region, in the extended sandy areas of Hungary (Figure 1). The annual mean temperature varies from 10.5 to $11.0^{\circ} \mathrm{C}$, the annual precipitation ranges from 500 to $600 \mathrm{~mm}$ (Bihari et al., 2018). The soil type of the largest sandy regions, e.g. Danube-Tisza Interfluve region and Nyírség, is characterized by mainly blown sand skeletal soil (arenosol) with low humus content (below 1\%). Sandy soils in the Transdanubian region and the Northern foothills are composed of sandy loam with up to $2 \%$ of organic matter content (Pásztor et al., 2018).

Pannonic sand steppes are protected at the EU level (code 6260; EC, 2013). Most extensive sand steppes are distributed in the Danube-Tisza Interfluve and Nyírség regions, and in smaller patches of other parts of the Great Hungarian Plain, the foothills 
of the North Hungarian Mountains and the Transdanubian region (Figure 1; Bölöni et al., 2011).

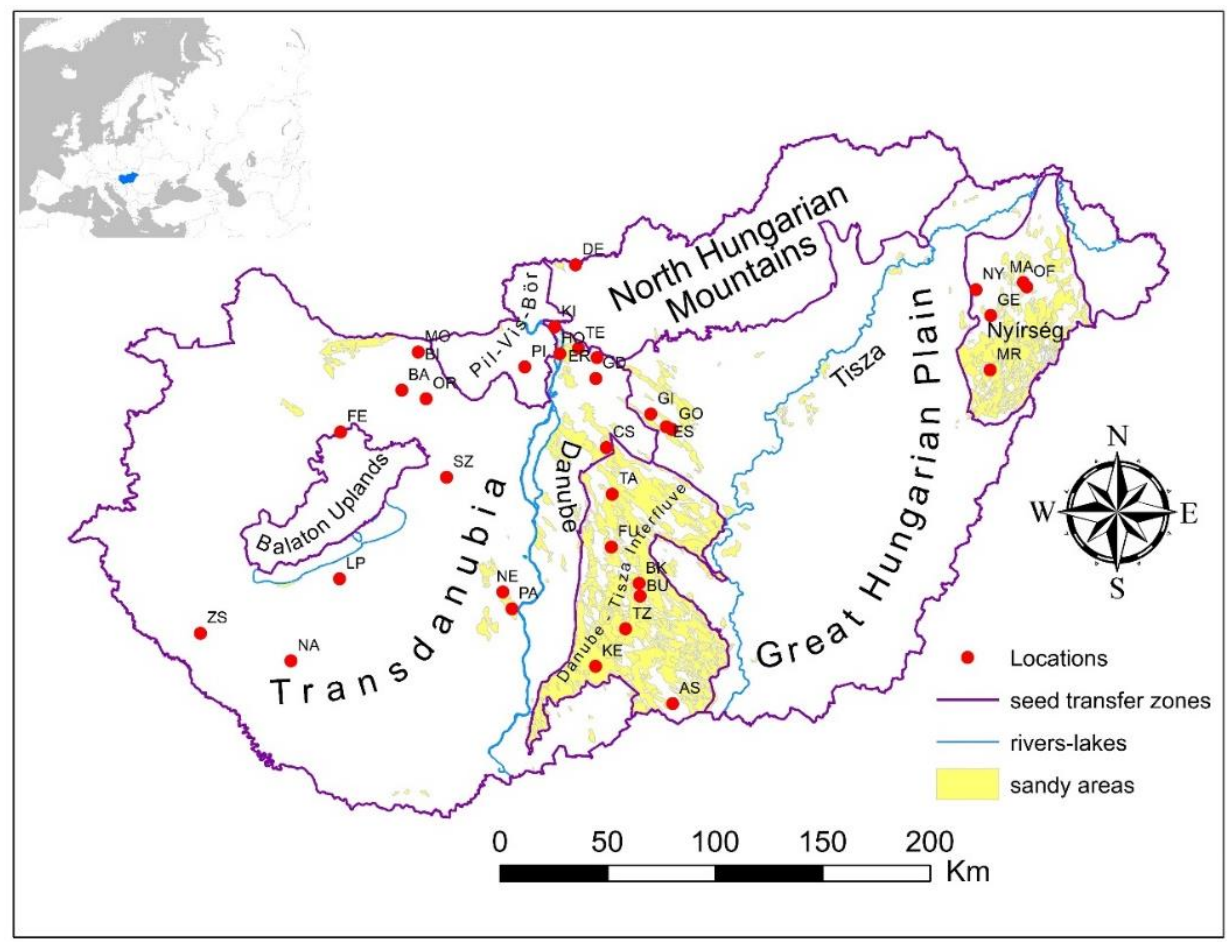

Figure 1. Map of locations of seed collection of the four species and main sandy regions in Hungary (Pásztor et al. 2018) with the seed transfer zone borders (Cevallos et al. 2020).

Location codes and coordinates can be found in Table S1. The Pilis-Visegrád-Börzsöny region is abbreviated as Pil-Vis-Bör.

\section{Field sampling}

The selection of species of the open sand steppe community was based on sampling the main constituent grasses and subordinate forbs. The selected species are sufficiently frequent to provide the necessary number of populations. Four native species were selected for the study. Two dominant grasses: Festuca vaginata, Stipa borysthenica, and two dominant forbs: Centaurea arenaria, and Dianthus serotinus. The seeds of the studied species (Figure 2) were collected in the growing season of 2019 from a total of 34 different locations within the Pannonian biogeographic region (Figure 1; Table S1), with different timing according to the ripening season of the given species, as follows: $S$. borysthenica in May-July; F. vaginata in June-July; C. arenaria in July; D. serotinus in August-September. The 34 sampled locations can be found in six STZs, which are: Transdanubia, Pilis-Visegrád-Börzsöny Mountains, Danube-Tisza Interfluve, North Hungarian Mountains, Great Hungarian Plain, and Nyírség (Cevallos et al., 2020). Seeds were harvested by hand at each location to collect approximately 50 seeds from 15 individuals. Seed families were treated as one sample. In the case of $S$. borysthenica that has a lower average seed yield per individual, we considered the seeds collected from neighboring individuals as one family and worked with fewer seeds in all the analyses. The seeds were stored at dry room conditions (temperature: $25 \pm 3{ }^{\circ} \mathrm{C}$, humidity: $38 \pm 4 \%$ ) until further processing. 


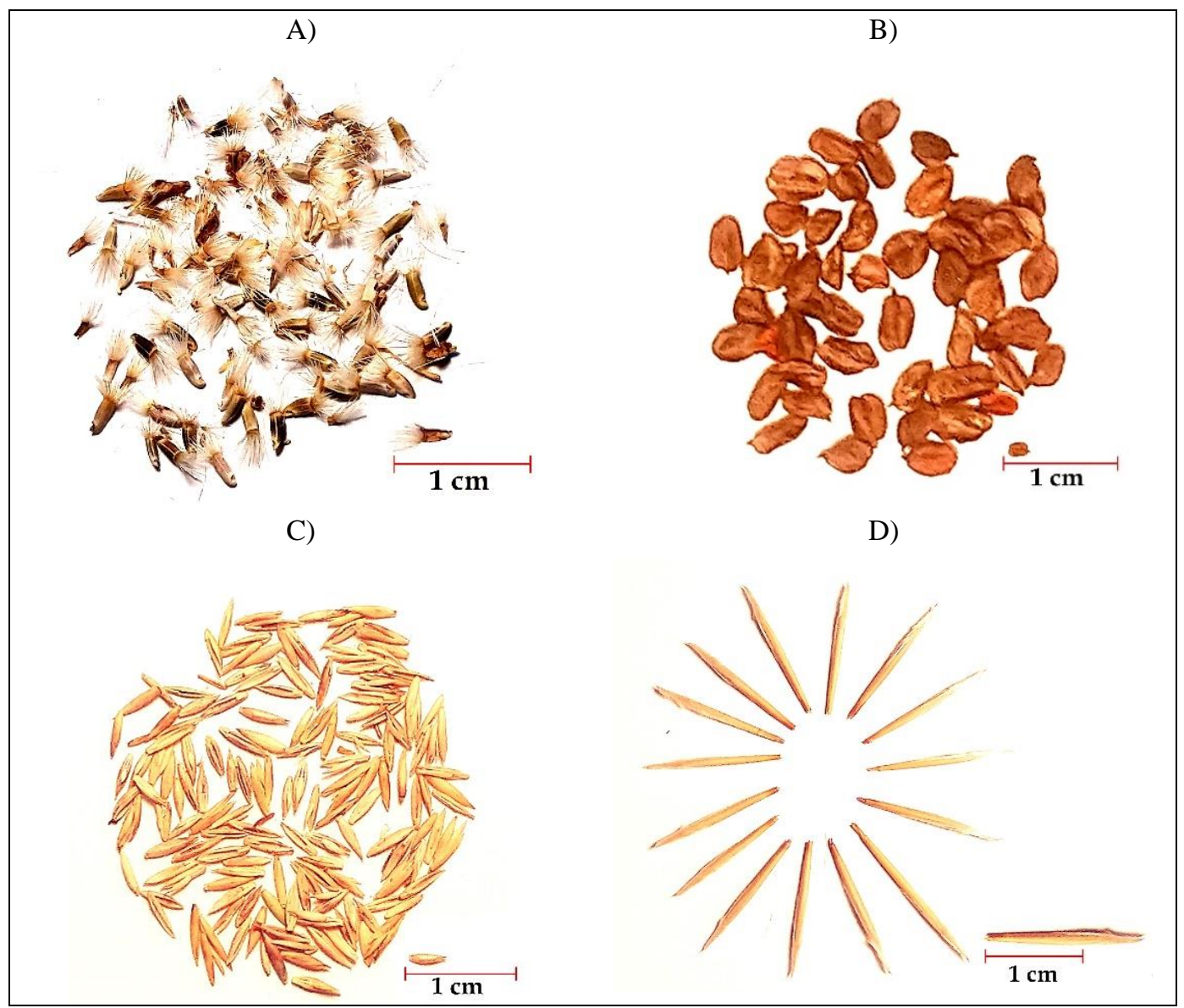

Figure 2. Seed photographs of A) Centaurea arenaria, B) Dianthus serotinus, C) Festuca vaginata, D) Stipa borysthenica.

\section{Seed mass and germination}

The dry weight of 50 seeds or 25 seeds (for S. borysthenica) from all locations (15 replicates each) was measured by an analytical balance with $0.0001 \mathrm{~g}$ accuracy. Seed mass was expressed as thousand seed weight in grams.

Two germination experiments were conducted: 1) under regulated conditions in a plant growth chamber and 2) in a common garden under outdoor conditions (irrigation was provided if necessary). Chamber germination tests were based on seed germination methods of Peti et al. (2017) and RBGK (2020). Thirty-five seeds (C. arenaria, $D$. serotinus, and $F$. vaginata) and ten seeds (S. borysthenica) of six samples per location per species were placed on wet filter paper in sterile Petri dishes and placed into an Aralab climatic chamber (FITOCLIMA D1200 PHL) with regulated temperature $\left(20^{\circ} \mathrm{C}\right)$, light ( $8 \mathrm{~h}$ light and $16 \mathrm{~h}$ dark) and humidity (50\%) conditions for all the species. Experiments were carried out between October 2019 and March 2020. Seed coats were not sterilized. The seed samples of $S$. borysthenica were treated by mechanical scarification to break seed dormancy. Germination was defined as the emergence of a $2 \mathrm{~mm}$ long radicle. The germinated seeds were counted and removed from the Petri dishes weekly for three weeks for C. arenaria, D. serotinus, and F. vaginata, and for nine weeks for S. borysthenica. The viability of non-germinated seeds was not further tested. 
A common garden experiment was established at a roof garden at the National Botanical Garden, Vácrátót $\left(47.708^{\circ} \mathrm{N}, 19.237^{\circ} \mathrm{E}\right)$. Average temperature: $10.75{ }^{\circ} \mathrm{C}$, average relative humidity: $73.37 \%$ (data obtained by wireless weather station data loggers between 31012020 and 30032021 on site). Fifteen seeds from each sample were manually sown in a regular layout: $5 \times 3$ seeds within a pot of $13 \times 13 \times 13 \mathrm{~cm}$. The seeds in a pot originated from one seed family (neighboring plants for S. borysthenica). Fifteen pots were seeded per location per species, resulting in 285 pots for $C$. arenaria, 240 for D. serotinus, 435 for $F$. vaginata, and 210 for $S$. borysthenica. Seeding was carried out in September 2019 for all species, emergence of the four studied species was monitored three times, in October 2019 and in March and April 2020. The cumulative emergence was used for the analyses.

\section{Data analysis}

The following three seed traits were selected for the analyses: seed mass expressed as thousand seed weight (TSW), the fraction of germinated seeds in a plant-growth chamber, and the cumulative seedling emergence in the outdoor common garden experiment. Average values of seed mass, germination and emergence, including standard errors are presented in Table $S 2$.

The effect of the provenance (sampling location) on the three seed traits for each species was evaluated by applying linear models (LM) and conducting Tukey HSD post hoc tests between pairs of locations to reveal significant differences (multcomp package; Hothorn et al. 2020) with p values adjusted by the method of Holm-Bonferroni (Holm, 1979). We calculated the rate of significant differences between locations (SDL) for each species by dividing the number of significant pairs by the total number of location pairs.

To assess the impact of geographical distance, the absolute difference of the mean values for each seed trait (seed mass, germination, and emergence) was calculated for each location pair. The Euclidean distance between the sampling locations was calculated based on their GPS coordinates. LM was used to determine the relationship between the difference of three seed trait values and geographical distance. In these models, the three seed traits were treated as response variables and Euclidean distance as an explanatory variable. The effect of ecological distance (STZs) on the three seed traits was assessed using separate LME models where mean values of each trait for each location were used as a response variable, whereas STZ zone identity served as a fixed effect, and locations were treated as a random factor. For post-hoc pairwise comparisons, Tukey HSD post hoc tests were applied using the multicomp package (Hothorn et al., 2020) with p values adjusted by the method of Holm-Bonferroni (Holm, 1979).

Aridity effects on the three seed traits were tested using LME models. In these analyses, aridity was treated as a fixed effect, the seed traits as response variables and the sampling location as a random factor. We used the Global Aridity Index to characterize the aridity of collection locations (Trabucco and Zomer, 2019). This index is represented by the ratio between mean annual precipitation and potential evapotranspiration with a resolution of 30 arc seconds, therefore lower values indicate higher aridity.

Square, cube root and squaring transformations of the response variables were used to approximate assumptions of normality and homoscedasticity when it was necessary. All statistical analyses were performed using the $\mathrm{R}$ version 3.6.2 ( $\mathrm{R}$ Core Team 2019). ArcGIS 10.2 was used to calculate the geographic distance. 


\section{Results}

\section{The effect of provenance}

The location of origin of the sampled populations significantly affected all seed traits (seed mass, germination, and emergence) for all studied species, except for the germination of $S$. borysthenica (Table 1). The rate of significant differences between locations (SDL) was variable among the species and the seed traits. S. borysthenica showed the highest rate of SDL for seed mass and emergence, while $C$. arenaria demonstrated the highest variability in germination. In the case of D. serotinus, the rate of significant differences was quite low (under 0.2) for all three traits. For $F$. vaginata, we found a low rate of SDL for seed mass and germination but a high rate for emergence.

Table 1. Effect of locations on the response variables for the study species. Linear models were used. Used transformations are shown. The number of significant differences of response variables between location pairs (SDL) versus total number of location pairs and their \% is given. Significant results are in bold.

\begin{tabular}{c|c|c|c|c|c|c}
\hline Species & Traits & Best conversion & F-value & df & p-value & SDL \\
\hline \multirow{4}{*}{ C. arenaria } & seed mass & no & $\mathbf{9 . 9 9 9}$ & $\mathbf{1 8}$ & $<\mathbf{0 . 0 5}$ & $52 / 171(0.3 \%)$ \\
& germination & cube root & $\mathbf{3 5 . 1 4 0}$ & $\mathbf{1 8}$ & $<\mathbf{0 . 0 5}$ & $102 / 171(0.63 \%)$ \\
& emergence & square root & $\mathbf{1 2 . 8 1 9}$ & $\mathbf{1 8}$ & $<\mathbf{0 . 0 5}$ & $58 / 171(0.34 \%)$ \\
\hline \multirow{3}{*}{ D. serotinus } & seed mass & no & $\mathbf{7 . 1 7 5}$ & $\mathbf{1 5}$ & $<\mathbf{0 . 0 5}$ & $22 / 120(0.18 \%)$ \\
& germination & squaring & $\mathbf{2 . 9 8 5}$ & $\mathbf{1 5}$ & $<\mathbf{0 . 0 5}$ & $3 / 120(0.03 \%)$ \\
& emergence & squaring & $\mathbf{5 . 9 8 9}$ & $\mathbf{1 5}$ & $<\mathbf{0 . 0 5}$ & $21 / 120(0.17 \%)$ \\
\hline \multirow{3}{*}{ F. vaginata } & seed mass & square root & $\mathbf{6 . 7 9 3}$ & $\mathbf{2 8}$ & $<\mathbf{0 . 0 5}$ & $37 / 406(0.09 \%)$ \\
& germination & no & $\mathbf{7 . 0 8 8}$ & $\mathbf{2 7}$ & $<\mathbf{0 . 0 5}$ & $43 / 378(0.11 \%)$ \\
& emergence & no & $\mathbf{1 5 . 3 7 5}$ & $\mathbf{2 8}$ & $<\mathbf{0 . 0 5}$ & $146 / 406(0.35 \%)$ \\
\hline \multirow{3}{*}{ S. borysthenica } & seed mass & squaring & $\mathbf{1 5 . 3 7 3}$ & $\mathbf{1 3}$ & $<\mathbf{0 . 0 5}$ & $41 / 91(0.45 \%)$ \\
& germination & square root & 1.9036 & 13 & 0.192 & $0 / 91(0 \%)$ \\
& emergence & squaring & $\mathbf{1 5 . 0 6 9}$ & $\mathbf{1 3}$ & $<\mathbf{0 . 0 5}$ & $37 / 91(0.4 \%)$ \\
\hline
\end{tabular}

\section{The effect of geographical and ecological distance}

There was no significant effect of the geographical distance on the measured seed traits (seed mass, germination, emergence) between populations from different locations, except for a significant effect for the emergence of $C$. arenaria (Table 2, Figure 3). The STZs had no effect on the response variables (seed mass, germination, emergence) for the studied species, except for the seed mass of $C$. arenaria $\left(\chi^{2}=8.47, \mathrm{df}=3, \mathrm{p}<0.05\right)$. In this case, the seed mass was significantly higher in the Great Hungarian Plain than in Transdanubia (z=-2.78, $\mathrm{p}=0.033$; Figure $S 1)$.

\section{The effect of aridity of the site}

The emergence of $C$. arenaria was negatively influenced by site aridity (higher aridity index, better emergence; $\chi^{2}=5.244, \mathrm{df}=1, \mathrm{p}<0.05$, Figure $4 a$ ). Site aridity had a positive effect (aridity index lower with higher trait values) both on germination and emergence of D. serotinus (germination: $\chi^{2}=5.159$, $\mathrm{df}=1, \mathrm{p}<0.05$; emergence: $\chi^{2}=6.375, \mathrm{df}=1$, $\mathrm{p}<0.05$; Figure 4b,c), when all sites considered (Figure 4b,c, line A). However, when sites with outlier high aridity index were skipped, no effect of aridity was found on D. serotinus seed traits (Figure 4b,c, line B). Site aridity had no effect on other species. 
Table 2. Effect of ecological distance (STZ), geographical distance and aridity on the response variables for the study species. Used transformations and models are shown. For linear models $(L M)$ results are shown with $F$ values whereas in linear mixed models (LME) with chisquare $\left(\chi^{2}\right)$ values. Significant results are in bold.

\begin{tabular}{|c|c|c|c|c|c|c|c|c|}
\hline Species & Trait & Parameter & model & $\begin{array}{c}\text { Best } \\
\text { conversion }\end{array}$ & $\chi^{2}$ & $\mathbf{F}$ & df & p \\
\hline \multirow{3}{*}{ C. arenaria } & Seed mass & $\begin{array}{c}\text { STZ } \\
\text { distance } \\
\text { aridity }\end{array}$ & $\begin{array}{c}\text { LME } \\
\text { LM } \\
\text { LME }\end{array}$ & $\begin{array}{c}\text { no } \\
\text { square root } \\
\text { no }\end{array}$ & $\begin{array}{l}8.470 \\
0.023\end{array}$ & 3.208 & $\begin{array}{l}3 \\
1 \\
1\end{array}$ & $\begin{array}{l}\mathbf{0 . 0 3 7} \\
0.075 \\
0.879\end{array}$ \\
\hline & germination & $\begin{array}{c}\text { STZ } \\
\text { distance } \\
\text { aridity }\end{array}$ & $\begin{array}{c}\text { LME } \\
\text { LM } \\
\text { LME }\end{array}$ & $\begin{array}{l}\text { square root } \\
\text { square root } \\
\text { square root }\end{array}$ & $\begin{array}{l}3.555 \\
1.483\end{array}$ & 0.185 & $\begin{array}{l}3 \\
1 \\
1\end{array}$ & $\begin{array}{l}0.314 \\
0.668 \\
0.223\end{array}$ \\
\hline & emergence & $\begin{array}{c}\text { STZ } \\
\text { distance } \\
\text { aridity } \\
\end{array}$ & $\begin{array}{c}\text { LME } \\
\text { LM } \\
\text { LME } \\
\end{array}$ & $\begin{array}{l}\text { square root } \\
\text { square root } \\
\text { square root }\end{array}$ & $\begin{array}{r}4.084 \\
5.244 \\
\end{array}$ & 7.160 & $\begin{array}{l}3 \\
1 \\
1 \\
\end{array}$ & $\begin{array}{l}0.253 \\
\mathbf{0 . 0 0 8} \\
\mathbf{0 . 0 2 2} \\
\end{array}$ \\
\hline \multirow{3}{*}{ D. serotinus } & Seed mass & $\begin{array}{c}\text { STZ } \\
\text { distance } \\
\text { aridity }\end{array}$ & $\begin{array}{c}\text { LME } \\
\text { LM } \\
\text { LME }\end{array}$ & $\begin{array}{c}\text { no } \\
\text { square root } \\
\text { no }\end{array}$ & $\begin{array}{l}0.711 \\
2.437 \\
\end{array}$ & 0.209 & $\begin{array}{l}3 \\
1 \\
1\end{array}$ & $\begin{array}{l}0.871 \\
0.649 \\
0.119\end{array}$ \\
\hline & germination & $\begin{array}{c}\text { STZ } \\
\text { distance } \\
\text { aridity } \\
\text { aridity } \\
\text { (nohigh) }\end{array}$ & $\begin{array}{c}\text { LME } \\
\text { LM } \\
\text { LME } \\
\text { LME }\end{array}$ & $\begin{array}{l}\text { squaring } \\
\text { cube root } \\
\text { squaring } \\
\text { squaring }\end{array}$ & $\begin{array}{l}4.014 \\
5.159 \\
0.006\end{array}$ & 1.243 & $\begin{array}{l}3 \\
1 \\
1 \\
1\end{array}$ & $\begin{array}{l}0.260 \\
0.267 \\
\mathbf{0 . 0 2 3} \\
0.939\end{array}$ \\
\hline & emergence & $\begin{array}{c}\text { STZ } \\
\text { distance } \\
\text { aridity } \\
\text { aridity } \\
\text { (nohigh) }\end{array}$ & $\begin{array}{c}\text { LME } \\
\text { LM } \\
\text { LME } \\
\text { LME } \\
\end{array}$ & $\begin{array}{l}\text { squaring } \\
\text { cube root } \\
\text { squaring } \\
\text { squaring }\end{array}$ & $\begin{array}{l}2.724 \\
6.215 \\
0.791 \\
\end{array}$ & 2.798 & $\begin{array}{l}3 \\
1 \\
1 \\
1 \\
\end{array}$ & $\begin{array}{l}0.428 \\
0.097 \\
\mathbf{0 . 0 1 3} \\
0.374 \\
\end{array}$ \\
\hline \multirow{3}{*}{ F. vaginata } & Seed mass & $\begin{array}{c}\text { STZ } \\
\text { distance } \\
\text { aridity } \\
\end{array}$ & $\begin{array}{c}\text { LME } \\
\text { LM } \\
\text { LME } \\
\end{array}$ & $\begin{array}{l}\text { square root } \\
\text { square root } \\
\text { square root }\end{array}$ & $\begin{array}{l}3.049 \\
0.725 \\
\end{array}$ & 0.074 & $\begin{array}{l}4 \\
1 \\
1 \\
\end{array}$ & $\begin{array}{l}0.550 \\
0.787 \\
0.395 \\
\end{array}$ \\
\hline & germination & $\begin{array}{c}\text { STZ } \\
\text { distance } \\
\text { aridity }\end{array}$ & $\begin{array}{c}\text { LME } \\
\text { LM } \\
\text { LME }\end{array}$ & $\begin{array}{c}\text { no } \\
\text { square root } \\
\text { no }\end{array}$ & $\begin{array}{l}2.466 \\
1.206\end{array}$ & 0.216 & $\begin{array}{l}4 \\
1 \\
1\end{array}$ & $\begin{array}{l}0.651 \\
0.643 \\
0.272\end{array}$ \\
\hline & emergence & $\begin{array}{c}\text { STZ } \\
\text { distance } \\
\text { aridity }\end{array}$ & $\begin{array}{c}\text { LME } \\
\text { LM } \\
\text { LME }\end{array}$ & $\begin{array}{c}\text { no } \\
\text { square root } \\
\text { no }\end{array}$ & $\begin{array}{l}2.392 \\
0.001\end{array}$ & 0.0005 & $\begin{array}{l}4 \\
1 \\
1\end{array}$ & $\begin{array}{l}0.664 \\
0.982 \\
0.974\end{array}$ \\
\hline \multirow{3}{*}{ S. borysthenica } & Seed mass & $\begin{array}{c}\text { STZ } \\
\text { distance } \\
\text { aridity }\end{array}$ & $\begin{array}{c}\text { LME } \\
\text { LM } \\
\text { LME }\end{array}$ & $\begin{array}{l}\text { squaring } \\
\text { square root } \\
\text { squaring }\end{array}$ & $\begin{array}{l}1.864 \\
0.316 \\
\end{array}$ & 2.292 & $\begin{array}{l}4 \\
1 \\
1 \\
\end{array}$ & $\begin{array}{l}0.761 \\
0.134 \\
0.574 \\
\end{array}$ \\
\hline & germination & $\begin{array}{c}\text { STZ } \\
\text { distance } \\
\text { aridity } \\
\end{array}$ & $\begin{array}{c}\text { LME } \\
\text { LM } \\
\text { LME } \\
\end{array}$ & $\begin{array}{l}\text { square root } \\
\text { square root } \\
\text { square root }\end{array}$ & $\begin{array}{l}6.086 \\
1.736 \\
\end{array}$ & 0.177 & $\begin{array}{l}4 \\
1 \\
1\end{array}$ & $\begin{array}{l}0.193 \\
0.675 \\
0.188\end{array}$ \\
\hline & emergence & $\begin{array}{c}\text { STZ } \\
\text { distance } \\
\text { aridity }\end{array}$ & $\begin{array}{c}\text { LME } \\
\text { LM } \\
\text { LME }\end{array}$ & $\begin{array}{l}\text { squaring } \\
\text { cube root } \\
\text { squaring }\end{array}$ & $\begin{array}{l}1.748 \\
0.057\end{array}$ & 1.310 & $\begin{array}{l}4 \\
1 \\
1\end{array}$ & $\begin{array}{l}0.782 \\
0.256 \\
0.811\end{array}$ \\
\hline
\end{tabular}




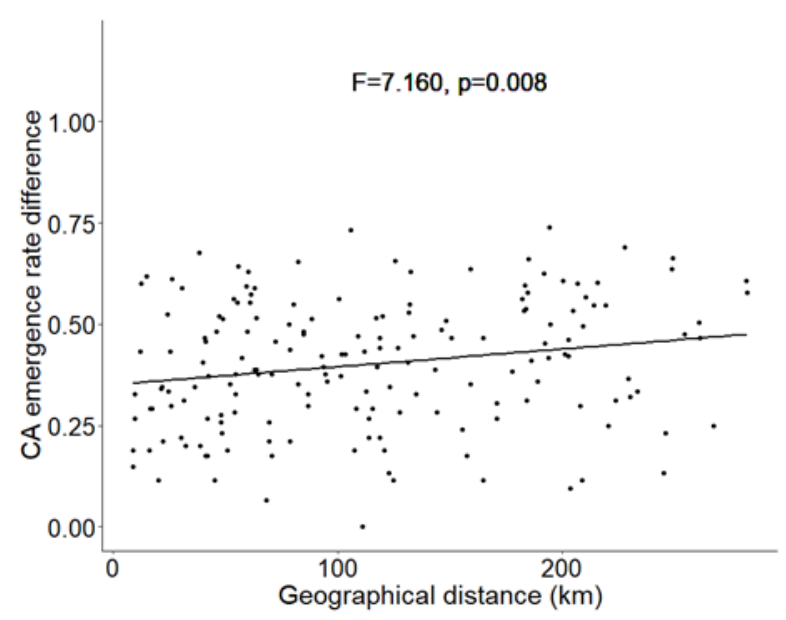

Figure 3. Relationship between C. arenaria emergence rate difference and geographical distance for locality pairs.

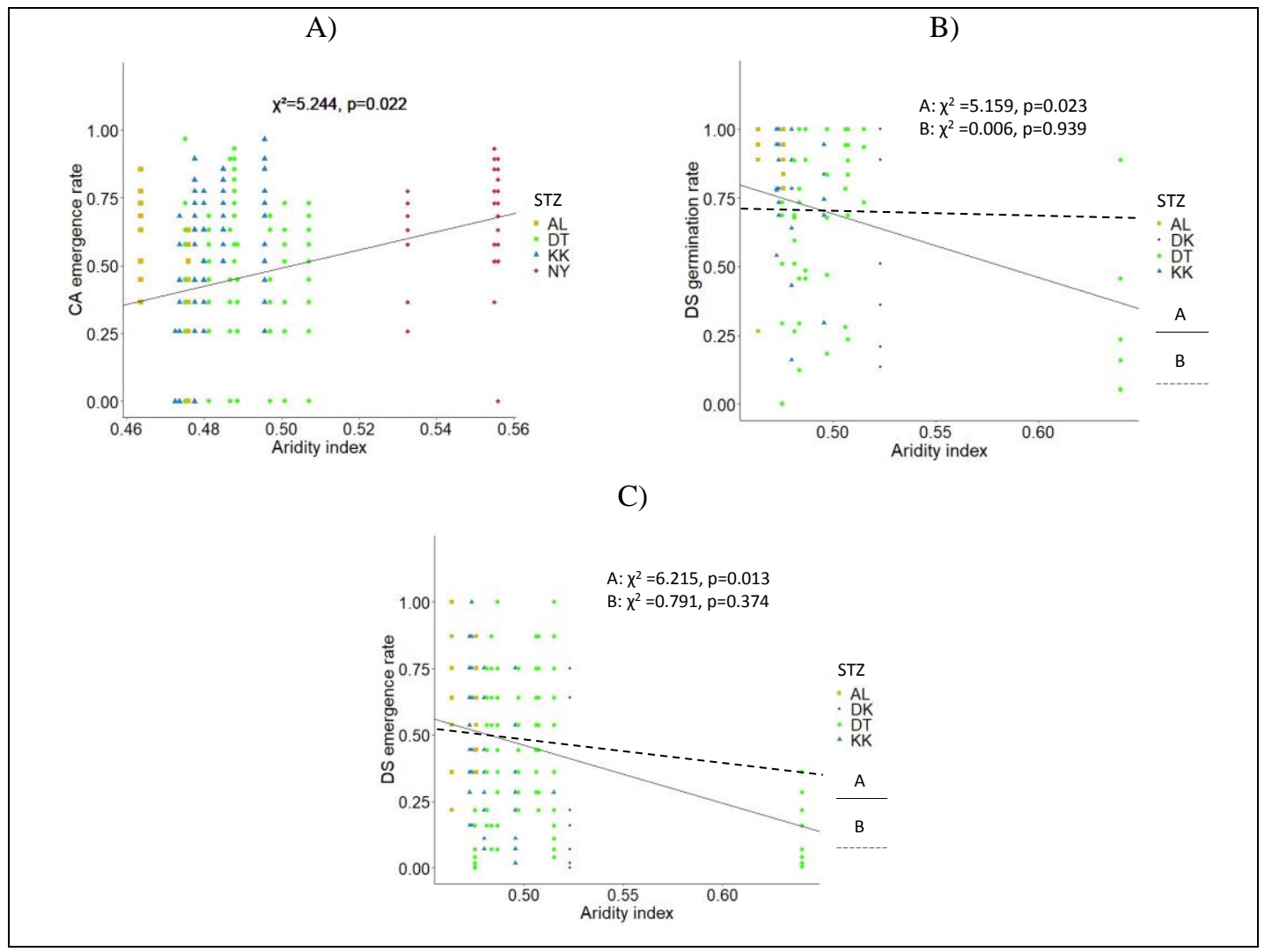

Figure 4. Significant effect of aridity of collection locations on $A)$ the emergence of $C$. arenaria $(C A) ; B)$ the germination of $D$. serotinus $(D S)$ and $C)$ the emergence of $D$. serotinus $(D S)$. For Figs $B$ and $C$, line $A$ represents all the values including locations with low aridity (high aridity index $>0.6)$, whereas line $B$ refers to the values excluding high aridity index locations. Note that higher value of the index refers to lower aridity. Locations coloured according to their seed transfer zones (STZ). Seed zones are represented with abbreviations: Great Hungarian Plain (AL, Alföld); Danube-Tisza Interfluve (KK, Kiskunság); Nyirség (NY); Pilis-Visegrád-Börzsöny region (DK); and the Transdanubia (DT, Dunántúl). 


\section{Discussion}

Our main aim was to shed light on the pattern of the variability of species traits among populations that can reflect local adaptation to avoid failure during reintroductions due to maladaptation. We tested multiple locations distributed in six of the seven STZs developed for Hungary (Cevallos et al., 2020) over a large area (approx. $40.000 \mathrm{~km}^{2}$ ); this level of sampling intensity is rather rare in studies, usually species from a few sites are investigated (Gibson et al., 2016; Bhatt et al., 2019).

We detected significant differences between provenance pairs, and the effect of location was significant for all four species characteristic to Pannonian sand grasslands considering every assessed seed trait. Seed mass is an important fitness trait (Cordazzo et al., 1995; Cochrane et al., 2015). The higher amount of resources in larger seeds provides an advantage for germination and emergence. It is however not clear, to what extent this advantage remains during emergence and development, and in later stages to support survival after introduction during restoration. In annual plants, the advantage of larger seeds can be detected even at the reproduction phase (Metz et al., 2010). Seed mass had high within-species variability in the present study among populations, as was reported in other studies as well (Cochrane et al., 2015; Bhatt et al., 2019; Elgabra et al., 2019). We found differences in the germination rate under laboratory conditions and the outdoor emergence for three species (C. arenaria, $D$. serotinus, and $F$. vaginata), similar to other research results (Clarke and Davidson, 2004; Kövendi-Jakó et al., 2017). The lack of this result for $S$. borysthenica can be explained by the fact that only very few seeds germinated under laboratory conditions, but emergence was variable among sites of origin, as for the other species. The mechanical scarification applied for breaking seed dormancy was ineffective, but the outdoor seeding with a prolonged incubation in the soil during the winter resulted in nearly $80 \%$ germination of $S$. borysthenica by spring. Seed dormancy breaking methods have to be further tested for this species, as it was done for S. tenacissima (Gasque and García-Fayos, 2003).

This within-species variability of seed traits is a signal of local adaptation of the different provenances, as it has been shown in numerous published common garden experiments for native species (Dorman et al., 2009; Bischoff et al., 2010), also aiming to test seed transfer zones (Bucharova et al., 2017; Durka et al., 2017; Gibson and Nelson, 2017). C. arenaria had the highest rate of significant differences between pairs of locations. This output could be the result of the high variability within this species as there are three subspecies in Hungary (Király, 2009).

The differences between locations in seed mass, germination and cumulative seedling emergence values were not explained by the geographical distance between populations unlike some other studies (Herrera et al., 2002; Baruch et al., 2004). However, it was also demonstrated in several cases that ecological distance (also expressed in STZs) is more important than geographical distance (Raabová et al., 2007; Bradburd et al., 2013; Durka et al., 2017). In our study, site aridity is represented by the precipitationevapotranspiration ratio, thus, lower values represent higher aridity. This value had a significant effect on the seed traits of the two forbs (C. arenaria and D. serotinus), but not on the two grass species ( $F$. vaginata and $S$. borysthenica). We found a significant negative effect of aridity on the emergence of $C$. arenaria. For D. serotinus, the effect of site aridity on the germination in the growth chamber was positive. However, in the latter case, if the three localities with aridity values above 0.6 were not considered, the positive effect diminished. Therefore, more studies on samples from locations with lower aridity would be needed in the future to confirm the reliability of this effect. The effect of aridity 
on the studied forbs suggests a higher sensitivity in early life traits regarding water availability compared to grasses. In contrast, Guo et al. (2017) found that both grasses and forbs, which were exposed to different aridity gradients showed an increase in leaf thickness with higher aridity. Aridity did not explain differences in seed mass in our studied species. Similar to our results, a study on seed traits also found the lack of environmental effect on the seed mass of Helianthus annuus (Hernández et al., 2019).

The differences in seed traits found do not correspond to the STZ delineation developed by using biogeographic maps and potential natural vegetation models (Cevallos et al., 2020). Raabová et al. (2007) found similarly no pattern in the local adaptation of a rare herb species, despite estimating genetic variation parallel to trait measurements. Only in the case of $C$. arenaria, we found a significant difference between two STZs (Great Hungarian Plain and Transdanubia) in seed weight. The most fragmented and remote populations in the Nyírség (Eastern part of the Great Hungarian Plain; Fig. 1) did not differ from the other zones for C. arenaria traits despite having the lowest aridity, among its sampled populations; however, the emergence of the same species was significantly affected by aridity.

The unfolding of the complex influences of the environment on the studied traits, and the importance of local adaptation compared to phenotypic plasticity needs other measurements and approaches. Further studies testing STZs can either focus on species at the genetic level (Jørgensen et al., 2016; Durka et al., 2017; Listl et al., 2018) or cover other traits and habitat types.

\section{Conclusions}

We found significant differences for all seed traits for the four species among the sampled locations. However, these differences did not correspond to STZ zones delineated based on biogeographic maps and potential natural vegetation models. We also found a limited effect of site aridity on the traits. Potentially the drivers of seed trait variability function at a finer scale. However, we can state that geographical, ecological (STZ), and environmental distance (aridity) had a stronger effect on the seed traits of the studied forbs than grasses. Based on our results, we suggest allowing seed transfer among the populations of the studied species over the sampled area. However, further studies are suggested to shed light on the relationship between other plant traits and seed transfer zones. Later life-history stages of the studied populations, the involvement of more populations, the implementation of reciprocal transplant experiments, the observation of phenotypic differences among populations in the further offspring to identify maternal effect are possible directions of research.

Acknowledgements. The study was financed by the Széchenyi 2020 Development Program (KEHOP4.3.0-VEKOP-15-2016-00001) (KT). The study of DC was supported by the Stipendium Hungaricum program. AKJ was supported by the National Talent Program (NTP-NFTÖ-19-B-0159). MH was supported by NKFI FK127996 grant.

\section{REFERENCES}

[1] Baruch, Z., Nassar, J. M., Bubis, J. (2004): Quantitative trait, genetic, environmental, and geographical distances among populations of the C4 grass Trachypogon plumosus in Neotropical savannas. - Diversity and Distributions 10(4): 283-292. 
[2] Bhatt, A., Bhat, N. R., Al-Nasser, A., Carón, M. M., Santo, A. (2019): Inter-population variabilities in seed mass and germination of Panicum turgidum and Pennisetum divisum on the desert of Kuwait. - Journal of Arid Land 12(1): 144-153.

[3] Bihari, Z., Babolcsai, G., Bartholy, J., Ferenczi, Z., Gerhát-Kerényi, J., Haszpra, L., Homoki-Ujváry, K., Kovács, T., Lakatos, M., Németh, Á., Pongrácz, R., Putsay, M., Szabó, P., Szépszó, G. (2018): Climate. - In: Kocsis, K. (ed.) National Atlas of Hungary: Natural environment (pp.59-63). Budapest: Hungarian Academy of Sciences, Research Centre for Astronomy and Earth Sciences, Geographical Institute. http://www.nemzetiatlasz.hu/MNA/2_en.html. (accessed 08 August 2020).

[4] Biró, M., Czúcz, B., Horváth, F., Révész, A., Csatári, B., Molnár, Z. (2013): Drivers of grassland loss in Hungary during the post-socialist transformation (1987-1999). Landscape ecology 28(5): 789-803.

[5] Bischoff, A., Müller-Schärer, H. (2010): Testing population differentiation in plant species-how important are environmental maternal effects. - Oikos 119(3): 445-454.

[6] Bischoff, A., Steinger, T., Müller-Schärer, H. (2010): The importance of plant provenance and genotypic diversity of seed material used for ecological restoration. - Restoration ecology 18(3): 338-348.

[7] Bölöni, J., Molnár, Z., Kun, A. (eds.) (2011): Magyarország élőhelyei. A hazai vegetációtípusok leírása és határozója. - ÁNÉR 2011. [Habitats of Hungary. A description and guide to Hungarian vegetation] [in Hungarian with English summaries]. MTA ÖBKI. 441p.

[8] Bower, A. D., Clair, J. B. S., Erickson, V. (2014): Generalized provisional seed zones for native plants. - Ecological Applications 24(5): 913-919.

[9] Bradburd, G. S., Ralph, P. L., Coop, G. M. (2013): Disentangling the effects of geographic and ecological isolation on genetic differentiation. - Evolution 67(11): 3258-3273.

[10] Breed, M. F., Harrison, P. A., Bischoff, A., Durruty, P., Gellie, N. J., Gonzales, E. K., Havens, K., Karmann, M., Kilkenny, F. F., Krauss, S. L., Lowe, A. J. (2018): Priority actions to improve provenance decision-making. - BioScience 68(7): 510-516.

[11] Breen, A. N., Richards, J. H. (2008): Irrigation and fertilization effects on seed number, size, germination and seedling growth: implications for desert shrub establishment. Oecologia 157(1): 13-19.

[12] Broadhurst, L. M., Lowe, A., Coates, D. J., Cunningham, S. A., McDonald, M., Vesk, P. A., Yates, C. (2008): Seed supply for broadscale restoration: maximizing evolutionary potential. - Evolutionary Applications 1(4): 587-597.

[13] Bucharova, A., Michalski, S., Hermann, J. M., Heveling, K., Durka, W., Hölzel, N., Kollmann, J., Bossdorf, O. (2017): Genetic differentiation and regional adaptation among seed origins used for grassland restoration: lessons from a multispecies transplant experiment. - Journal of Applied Ecology 54(1): 127-136.

[14] Bucharova, A., Bossdorf, O., Hölzel, N., Kollmann, J., Prasse, R., Durka, W. (2019): Mix and match: regional admixture provenancing strikes a balance among different seedsourcing strategies for ecological restoration. - Conservation Genetics 20(1): 7-17.

[15] Cevallos, D., Bede-Fazekas, Á., Tanács, E., Szitár, K., Halassy, M., Kövendi-Jakó, A., Török, K. (2020): Seed transfer zones based on environmental variables better reflect variability in vegetation than administrative units: evidence from Hungary. - Restoration Ecology 28(4): 911-918.

[16] Clarke, P. J., Davison, E. A. (2004): Emergence and survival of herbaceous seedlings in temperate grassy woodlands: recruitment limitations and regeneration niche. - Austral Ecology 29(3): 320-331.

[17] Cochrane, A., Yates, C. J., Hoyle, G. L., Nicotra, A. B. (2015): Will among-population variation in seed traits improve the chance of species persistence under climate change? Global Ecology and Biogeography 24(1): 12-24. 
[18] Cordazzo, C. V., Greipsson, S., Davy, A. J. (1995): Seed mass and germination behaviour in populations of the dune-building grass Leymus arenarius. - Annals of Botany 76(5): 493-501.

[19] Donohue, K., Rubio de Casas, R., Burghardt, L., Kovach, K., Willis, C. G. (2010): Germination, postgermination adaptation, and species ecological ranges. - Annual review of ecology, evolution, and systematics 41: 293-319.

[20] Dorman, M., Sapir, Y., Volis, S. (2009): Local adaptation in four Iris species tested in a common-garden experiment. - Biological Journal of the Linnean Society 98(2): 267-277.

[21] Drenovsky, R. E., Richards, J. H. (2005): Nitrogen addition increases fecundity in the desert shrub Sarcobatus vermiculatus. - Oecologia 143(3): 349-356.

[22] Durka, W., Michalski, S. G., Berendzen, K. W., Bossdorf, O., Bucharova, A., Hermann, J. M., Hölzel, N., Kollmann, J. (2017): Genetic differentiation within multiple common grassland plants supports seed transfer zones for ecological restoration. - Journal of Applied Ecology 54(1): 116-126.

[23] EC (European Commission) (2008): LIFE and Europe's grasslands: Restoring a forgotten habitat. $\quad-\quad$ https://ec.europa.eu/environment/archives/life/publications/lifepublications/lifefocus/documents/grassland.pdf. (accessed 30 July 2020).

[24] EC (European Commission) (2013): Interpretation manual of European Union habitats. https://ec.europa.eu/environment/nature/legislation/habitatsdirective/docs/Int_Manual_E U28.pdf. (accessed 20 August 2020).

[25] Elgabra, M., El-Keblawy, A., Mosa, K. A., Soliman, S. (2019): Factors controlling seed dormancy and germination response of Brachypodium hybridum growing in the hot arid mountains of the Arabian Desert. - Botany 97(7): 371-379.

[26] Fry, E. L., Evans, A. L., Sturrock, C. J., Bullock, J. M., Bardgett, R. D. (2018): Root architecture governs plasticity in response to drought. - Plant and soil 433(1): 189-200.

[27] Gasque, M., García-Fayos, P. (2003): Seed dormancy and longevity in Stipa tenacissima L. (Poaceae). - Plant Ecology 168(2): 279-290.

[28] Germino, M. J., Moser, A. M., Sands, A. R. (2019): Adaptive variation, including local adaptation, requires decades to become evident in common gardens. - Ecological Applications 29(2): e01842.

[29] Gibson, A. L., Espeland, E. K., Wagner, V., Nelson, C. R. (2016): Can local adaptation research in plants inform selection of native plant materials? An analysis of experimental methodologies. - Evolutionary Applications 9(10): 1219-1228.

[30] Gibson, A., Nelson, C. R. (2017): Comparing provisional seed transfer zone strategies for a commonly seeded grass, Pseudoroegneria spicata. - Natural Areas Journal 37(2): 188199.

[31] Gibson, A., Nelson, C. R., Rinehart, S., Archer, V., Eramian, A. (2019): Importance of considering soils in seed transfer zone development: evidence from a study of the native Bromus marginatus. - Ecological Applications 29(2): e01835.

[32] Guo, C., Ma, L., Yuan, S., Wang, R. (2017): Morphological, physiological and anatomical traits of plant functional types in temperate grasslands along a large-scale aridity gradient in northeastern China. - Scientific reports 7(1): 1-10.

[33] Hernández, F., Poverene, M., Garayalde, A., Presotto, A. (2019): Re-establishment of latitudinal clines and local adaptation within the invaded area suggest rapid evolution of seed traits in Argentinean sunflower (Helianthus annuиs L.). - Biological Invasions 21(8): 2599-2612.

[34] Herrera, C. M., Cerdá, X., Garcia, M. B., Guitián, J., Medrano, M., Rey, P. J., SánchezLafuente, A. M. (2002): Floral integration, phenotypic covariance structure and pollinator variation in bumblebee-pollinated Helleborus foetidus. - Journal of Evolutionary Biology 15(1): 108-121.

[35] Holm, S. (1979): A simple sequentially rejective multiple test procedure. - Scandinavian journal of statistics 6: 65-70. 
[36] Hothorn, T., Bretz, F., Westfall, F., Heiberger, R., Schuetzenmeister, A., Scheibe, S. (2020): The multcomp package. - https://www.rdocumentation.org/pack-ages/multcomp. (accessed 08 August 2020).

[37] Hufford, K. M., Mazer, S. J. (2003): Plant ecotypes: genetic differentiation in the age of ecological restoration. - Trends in Ecology \& Evolution 18(3): 147-155.

[38] Johnson, R. C., Erickson, V. J., Mandel, N. L., St Clair, J. B., Vance-Borland, K. W. (2010): Mapping genetic variation and seed zones for Bromus carinatus in the Blue Mountains of eastern Oregon, USA. - Botany 88(8): 725-736.

[39] Jørgensen, M. H., Elameen, A., Hofman, N., Klemsdal, S., Malaval, S., Fjellheim, S., (2016): What's the meaning of local? Using molecular markers to define seed transfer zones for ecological restoration in Norway. - Evolutionary applications 9(5): 673-684.

[40] Kiehl, K., Kirmer, A., Donath, T. W., Rasran, L., Hölzel, N. (2010): Species introduction in restoration projects-Evaluation of different techniques for the establishment of seminatural grasslands in Central and Northwestern Europe. - Basic and Applied Ecology 11(4): 285-299.

[41] Kiehl, K., Kirmer, A., Shaw, N. (eds.) (2014): Guidelines for native seed production and grassland restoration. - Cambridge Scholars Publishing.

[42] Király, G. (2009): Új magyar füvészkönyv. Magyarország hajtásos növényei. Határozókulcs. Abrák [New Hungarian herbal. Vascular plants of Hungary. Identification keys]. - Aggteleki Nemzeti Park Igazgatóság, Jósvafö, Hungary.

[43] Kövendi-Jakó, A., Csecserits, A., Halassy, M., Halász, K., Szitár, K., Török, K. (2017): Relationship of germination and establishment for twelve plant species in restored dry grassland. - Applied Ecology and Environmental Research 15(4): 227-239.

[44] Kövendi-Jakó, A., Halassy, M., Csecserits, A., Hülber, K., Szitár, K., Wrbka, T., Török, K. (2019): Three years of vegetation development worth 30 years of secondary succession in urban-industrial grassland restoration. - Applied Vegetation Science 22(1): 138-149.

[45] Leger, E. A., Rice, K. J. (2007): Assessing the speed and predictability of local adaptation in invasive California poppies (Eschscholzia californica). - Journal of evolutionary biology 20(3): 1090-1103.

[46] Leimu, R., Fischer, M. (2008): A meta-analysis of local adaptation in plants. - PloS one 3(12): e4010.

[47] Lengyel, S., Varga, K., Kosztyi, B., Lontay, L., Déri, E., Török, P., Tóthmérész, B. (2012): Grassland restoration to conserve landscape-level biodiversity: a synthesis of early results from a large-scale project. - Applied Vegetation Science 15(2): 264-276.

[48] Listl, D., Poschlod, P., Reisch, C. (2018): Do seed transfer zones for ecological restoration reflect the spatial genetic variation of the common grassland species Lathyrus pratensis? Restoration Ecology 26(4): 667-676.

[49] Macel, M., Lawson, C. S., Mortimer, S. R., Šmilauerova, M., Bischoff, A., Crémieux, L., Doležal, J., Edwards, A. R., Lanta, V., Bezemer, T. M., Van der Putten, W. H. (2007): Climate vs. soil factors in local adaptation of two common plant species. - Ecology 88(2): 424-433.

[50] McDowell, N., Pockman, W. T., Allen, C. D., Breshears, D. D., Cobb, N., Kolb, T., Plaut, J., Sperry, J., West, A., Williams, D. G., Yepez, E. A. (2008): Mechanisms of plant survival and mortality during drought: why do some plants survive while others succumb to drought? - New phytologist 178(4): 719-739.

[51] McKay, J. K., Christian, C. E., Harrison, S., Rice, K. J. (2005): How local is local? - a review of practical and conceptual issues in the genetics of restoration. - Restoration Ecology 13(3): 432-440.

[52] Merritt, D. J., Dixon, K. W. (2011): Restoration seed banks - a matter of scale. - Science 332(6028): 424-425.

[53] Metz, J., Liancourt, P., Kigel, J., Harel, D., Sternberg, M., Tielbörger, K. (2010): Plant survival in relation to seed size along environmental gradients: a long-term study from 
semi-arid and Mediterranean annual plant communities. - Journal of Ecology 98(3): 697704.

[54] Mijnsbrugge, K., Bischoff, A., Smith, B. (2010): A question of origin: where and how to collect seed for ecological restoration. - Basic and Applied Ecology 11(4): 300-311.

[55] Miller, S. A., Bartow, A., Gisler, M., Ward, K., Young, A. S., Kaye, T. N. (2011): Can an ecoregion serve as a seed transfer zone? Evidence from a common garden study with five native species. - Restoration Ecology 19(201): 268-276.

[56] Pásztor, L., Bakacsi, Zs., Laborczi, A., Szabó, J. (2013): Downscaling of categorical soil maps with the aid of auxiliary spatial soil information and data mining methods (Kategória típusú talajtérképek térbeli felbontásának javítása kiegészítő talajtani adatok és adatbányászati módszerek segítségével. In Hungarian). - Agrokémia és Talajtan 62: 205218.

[57] Pásztor, L., Dobos, E., Michéli, E., Várallyay, G. (2018): Soils. - In: Kocsis, K. (ed.) National Atlas of Hungary: Natural environment (pp. 82-92). Budapest: Hungarian Academy of Sciences, Research Centre for Astronomy and Earth Sciences, Geographical Institute. http://www.nemzetiatlasz.hu/MNA/2_en.html. (accessed 08 August 2020).

[58] Peti, E., Schellenberger, J., Németh, G., Málnási Csizmadia, G., Oláh, I., Török, K., Czóbel, S. (2017): Presentation of the HUSEEDwild-a seed weight and germination database of the Pannonian flora-through analysing life forms and social behaviour types. - Applied Ecology and Environmental Research 15(1): 225-244.

[59] Postma, F. M., Ågren, J. (2016): Early life stages contribute strongly to local adaptation in Arabidopsis thaliana. - Proceedings of the National Academy of Sciences 113(27): 75907595.

[60] R Core Team (2019): R: A language and environment for statistical computing. - R Foundation for Statistical Computing. https://www.R-project.org/. (accessed 20 March 2020).

[61] Raabová, J., Münzbergová, Z., Fischer, M. (2007): Ecological rather than geographic or genetic distance affects local adaptation of the rare perennial herb, Aster amellus. Biological Conservation 139(3-4): 348-357.

[62] RBGK (Royal Botanic Gardens Kew) (2020): Seed Information Database (SID). Version 7.1. - http://data.kew.org/sid/ (accessed 18 March 2020).

[63] Reiker, J., Schulz, B., Wissemann, V., Gemeinholzer, B. (2015): Does origin always matter? Evaluating the influence of nonlocal seed provenances for ecological restoration purposes in a widespread and outcrossing plant species. - Ecology and evolution 5(23): $5642-5651$.

[64] St. Clair, J., Kilkenny, F. F., Johnson, R. C., Shaw, N. L., Weaver, G. (2013): Genetic variation in adaptive traits and seed transfer zones for Pseudoroegneria spicata (bluebunch wheatgrass) in the northwestern United States. - Evolutionary Applications 6(6): 933-948.

[65] Török, P., Vida, E., Deák, B., Lengyel, S., Tóthmérész, B. (2011): Grassland restoration on former croplands in Europe: an assessment of applicability of techniques and costs. Biodiversity and Conservation 20(11): 2311-2332.

[66] Török, P., Dengler, J. (2018): Palaearctic grasslands in transition: overarching patterns and future prospects. - Grasslands of the world: Diversity, management and conservation, pp. 15-26.

[67] Trabucco, A., Zomer, R. (2019): Global Aridity Index and Potential Evapotranspiration. (ET0) Climate Database v2. figshare. Dataset. 


\section{APPENDIX}

The R scripts and the basic data are available upon request: david.cevallos@ecolres.hu.

Table S1. Locations with coordinates, STZ, aridity and fertility values of the seed collection from the studies species. STZ Codes: AL: Great Hungarian plain (Hungarian: Alföld), DK: Pilis-Visegrád-Börzsöny region, DT: Transdanubia (Dunántúl), EH: North Hungarian mountains (Ėszakiközéphegység), KK: Danube-Tisza Interfluve (Kiskunság), NY: Nyirség. Aridity represents the ratio of mean annual temperature and evapotranspiration based on the (Global-ET0) Version 2 global dataset, with high resolution ( 30 arc-seconds). The timeframe of the weather data was from 1970 to 2000 (Trabucco and Zomer, 2019), and soil fertility values were obtained from the soil productivity map of Hungary in an ordinal scale (Pásztor et al., 2013).

\begin{tabular}{|c|c|c|c|c|c|c|c|c|}
\hline \multirow[b]{2}{*}{ Code } & \multirow[b]{2}{*}{ Location name } & \multicolumn{2}{|c|}{ Coordinates } & \multirow[b]{2}{*}{ STZ Code } & \multicolumn{4}{|c|}{ Studied species } \\
\hline & & Latitude & Longitude & & $\begin{array}{c}\text { Centaurec } \\
\text { arenaria }\end{array}$ & $\begin{array}{l}\text { a Dianthus } \\
\text { serotinus }\end{array}$ & $\begin{array}{l}\text { Festuca } \\
\text { vaginatabc }\end{array}$ & $\begin{array}{c}\text { Stipa } \\
\text { orysthenica }\end{array}$ \\
\hline AS & Ásotthalom & N46 $12^{\prime} 50,63^{\prime \prime}$ & E19 $47^{\prime} 18,77^{\prime \prime}$ & KK & $\checkmark$ & $\checkmark$ & $\checkmark$ & $\checkmark$ \\
\hline BA & Bársonyos & $\mathrm{N} 47^{\circ} 31^{\prime} 25,20^{\prime \prime}$ & E180 08' 02,31" & DT & & $\checkmark$ & $\checkmark$ & \\
\hline $\mathrm{BI}$ & Billegpuszta & N47 $41^{\prime} 01,96^{\prime \prime}$ & E18 $14^{\prime} 00,98^{\prime \prime}$ & DT & & $\checkmark$ & & \\
\hline BU & Bugac & N46 $39^{\prime} 54,05^{\prime \prime}$ & E19 $35^{\prime} 47,07^{\prime \prime}$ & KK & $\checkmark$ & & $\checkmark$ & $\checkmark$ \\
\hline BK & Bugac külső & N46 $43^{\prime} 04,80^{\prime \prime}$ & E19 $35^{\prime} 27,88^{\prime \prime}$ & KK & & & $\checkmark$ & $\checkmark$ \\
\hline $\mathrm{CS}$ & Csévharaszt & N47 $17^{\prime} 12,27^{\prime \prime}$ & E192 23' 44,89" & DT & $\checkmark$ & $\checkmark$ & $\checkmark$ & $\checkmark$ \\
\hline DE & Dejtár & N48 $03^{\circ} 06,00^{\prime \prime}$ & E19 12' 32,35" & $\mathrm{EH}$ & & & & $\checkmark$ \\
\hline ER & Erdőkertes & N47 $39^{\prime} 46,79^{\prime \prime}$ & E19 $20^{\prime} 26,11^{\prime \prime}$ & DT & $\checkmark$ & $\checkmark$ & $\checkmark$ & $\checkmark$ \\
\hline ES & Erdőszőlő & $\mathrm{N} 47^{\circ} 22^{\prime} 18,35^{\prime \prime}$ & E19 $45^{\prime} 55,33^{\prime \prime}$ & $\mathrm{AL}$ & & & & $\checkmark$ \\
\hline FE & Fenyőfö & N47 $20^{\prime} 42,06^{\prime \prime}$ & E17 $45^{\prime} 36,96^{\prime \prime}$ & DT & & & $\checkmark$ & \\
\hline FU & Fülöpháza & N46 $52^{\prime} 14,59^{\prime \prime}$ & E19 $25^{\prime} 24,31^{\prime \prime}$ & KK & $\checkmark$ & $\checkmark$ & $\checkmark$ & $\checkmark$ \\
\hline GE & Geszteréd & $\mathrm{N} 47^{\circ} 48^{\prime} 27,21^{\prime \prime}$ & E21 ${ }^{\circ} 47^{\prime} 09,34^{\prime \prime}$ & NY & $\checkmark$ & & & \\
\hline GI & Gicei-hegy & N47 $25^{\prime} 32,27^{\prime \prime}$ & E19 $40^{\prime} 14,72^{\prime \prime}$ & $\mathrm{AL}$ & $\checkmark$ & $\checkmark$ & $\checkmark$ & \\
\hline GO & Göbölyjárás & $\mathrm{N} 47^{\circ} 21^{\prime} 38,73^{\prime \prime}$ & E19 $47^{\prime} 59,19^{\prime \prime}$ & AL & $\checkmark$ & $\checkmark$ & $\checkmark$ & \\
\hline GD & Gödöllö & N47 $34^{\prime} 33,59^{\prime \prime}$ & E19 19' 55,19" & DT & $\checkmark$ & & $\checkmark$ & \\
\hline $\mathrm{HO}$ & Horány & N47 $40^{\prime} 45,54^{\prime \prime}$ & E1906' 36,78" & DT & $\checkmark$ & $\checkmark$ & $\checkmark$ & $\checkmark$ \\
\hline $\mathrm{KE}$ & Kéleshalom & N46 $22^{\prime} 20,09^{\prime \prime}$ & E19 $19^{\prime} 26,95^{\prime \prime}$ & KK & $\checkmark$ & $\checkmark$ & $\checkmark$ & $\checkmark$ \\
\hline $\mathrm{KI}$ & Kisoroszi & N47 $47^{\prime} 31,55^{\prime \prime}$ & E190 04' 41,66" & DT & $\checkmark$ & & $\checkmark$ & $\checkmark$ \\
\hline LP & Látránypuszta & N46 $43^{\prime} 52,73^{\prime \prime}$ & E17 46' 06,89" & DT & & & $\checkmark$ & \\
\hline
\end{tabular}

APPLIED ECOLOGY AND ENVIRONMENTAL RESEARCH 19(5):4129-4149.

http://www.aloki.hu • ISSN 15891623 (Print) • ISSN 17850037 (Online)

DOI: http://dx.doi.org/10.15666/aeer/1905_41294149

(c) 2021, ALÖKI Kft., Budapest, Hungary 


\begin{tabular}{|c|c|c|c|c|c|c|c|c|}
\hline \multirow[b]{2}{*}{ Code } & \multirow[b]{2}{*}{ Location name } & \multicolumn{2}{|c|}{ Coordinates } & & \multicolumn{4}{|c|}{ Studied species } \\
\hline & & Latitude & Longitude & STZ Code & $\begin{array}{c}\text { Centaure } \\
\text { arenaric }\end{array}$ & $\begin{array}{l}\text { a Dianthus } \\
\text { serotinus }\end{array}$ & $\begin{array}{l}\text { Festuca } \\
\text { vaginatab }\end{array}$ & $\begin{array}{c}\text { Stipa } \\
\text { orysthenica }\end{array}$ \\
\hline MA & Magy & N47 $56^{\prime} 25,90^{\prime \prime}$ & E21 ${ }^{\circ} 59^{\prime} 40,95^{\prime \prime}$ & NY & & & $\checkmark$ & \\
\hline MR & Martinka & N47 $34^{\prime} 47,24^{\prime \prime}$ & $\mathrm{E} 21^{\circ} 46^{\prime} 12,42^{\prime \prime}$ & NY & $\checkmark$ & & $\checkmark$ & \\
\hline MO & Mocsa & N47 $41^{\prime} 01,88^{\prime \prime}$ & E18 $13^{\circ} 59,35^{\prime \prime}$ & DT & & & $\checkmark$ & $\checkmark$ \\
\hline NA & Nagybajom & N46 $23^{\prime} 04,38^{\prime \prime}$ & $\mathrm{E} 17^{\circ} 29^{\prime} 00,02^{\prime \prime}$ & DT & & $\checkmark$ & $\checkmark$ & \\
\hline $\mathrm{NE}$ & Németkér & N46 $41^{\prime} 00,58^{\prime \prime}$ & E18 $45^{\prime} 46,33^{\prime \prime}$ & DT & $\checkmark$ & $\checkmark$ & $\checkmark$ & \\
\hline NY & Nyíregyházi lőtér & N47 $55^{\prime} 01,71^{\prime \prime}$ & $\mathrm{E} 21^{\circ} 41^{\prime} 58,68^{\prime \prime}$ & NY & & & $\checkmark$ & \\
\hline $\mathrm{OF}$ & Ófehértó & N47 $55^{\prime} 15,81^{\prime \prime}$ & $\mathrm{E} 22^{\circ} 00^{\prime} 59,11^{\prime \prime}$ & NY & $\checkmark$ & & & \\
\hline OR & Oroszlány & N47 $29^{\prime} 18,94^{\prime \prime}$ & $\mathrm{E} 18^{\circ} 17^{\prime} 05,89$ & DT & & $\checkmark$ & $\checkmark$ & \\
\hline PA & Paks & N46 $36^{\prime} 45,96^{\prime \prime}$ & E18 $49^{\prime} 05,06^{\prime \prime}$ & DT & $\checkmark$ & $\checkmark$ & $\checkmark$ & \\
\hline PI & Pilisvörösvár & N47 $37^{\prime} 27,61^{\prime \prime}$ & E18 $53^{\prime} 35,13^{\prime \prime}$ & DK & & $\checkmark$ & $\checkmark$ & $\checkmark$ \\
\hline $\mathrm{SZ}$ & Székesfehérvár & $\mathrm{N} 47^{\circ} 09^{\prime} 40,55^{\prime \prime}$ & E182 24' 54,22" & DT & & & $\checkmark$ & \\
\hline TA & Táborfalva & N47 $05^{\prime} 30,31^{\prime \prime}$ & $\mathrm{E} 19^{\circ} 25^{\prime} 48,54^{\prime \prime}$ & KK & $\checkmark$ & $\checkmark$ & $\checkmark$ & \\
\hline $\mathrm{TZ}$ & Tázlár & N46ㅇ $31^{\prime} 41,46^{\prime \prime}$ & $\mathrm{E} 19^{\circ} 30^{\prime} 25,90^{\prime \prime}$ & KK & $\checkmark$ & & $\checkmark$ & \\
\hline $\mathrm{TE}$ & Tece (Vácrátót) & N47 $42^{\prime} 07,74^{\prime \prime}$ & E19 $13^{\prime} 32,13^{\prime \prime}$ & DT & $\checkmark$ & & $\checkmark$ & $\checkmark$ \\
\hline \multirow[t]{2}{*}{$\mathrm{ZS}$} & Zsigárdmajor & N46' 29' $26,30^{\prime \prime}$ & $\mathrm{E} 16^{\circ} 55^{\prime} 55,49^{\prime \prime}$ & DT & & & $\checkmark$ & \\
\hline & & & Total locations & & 19 & 16 & 29 & 14 \\
\hline
\end{tabular}


Table S2. Average values \pm standard error of seed traits for each species organized by location. (*** not enough seeds for germination). Seed mass is expressed in grams, gemination and emergence in ratio. The sample size is in italics and it is represented for the seed mass by the number of measurements per location, and for the germination and emergence by the total number of seeds used in the measurements. Location codes are in Table S1.

\begin{tabular}{|c|c|c|c|c|c|c|c|c|c|c|c|c|}
\hline \multirow[t]{2}{*}{ Location } & \multicolumn{3}{|c|}{ Centaurea arenaria } & \multicolumn{3}{|c|}{ Dianthus serotinus } & \multicolumn{3}{|c|}{ Festuca vaginata } & \multicolumn{3}{|c|}{ Stipa borysthenica } \\
\hline & seed mass & germination & emergence & seed mass & germination & emergence & seed mass & germination & emergence & seed mass & germinatios & mergence \\
\hline AS & $\begin{array}{c}1.792 \\
\pm 0.076 \\
15\end{array}$ & $\begin{array}{c}0.181 \\
\pm 0.079 \\
210\end{array}$ & $\begin{array}{c}0.262 \\
\pm 0.043 \\
225\end{array}$ & $\begin{array}{c}0.498 \pm 0.030 \\
15\end{array}$ & $\begin{array}{c}0.780 \\
\pm 0.090 \\
210\end{array}$ & $\begin{array}{c}0.573 \\
\pm 0.055 \\
225\end{array}$ & $\begin{array}{c}0.395 \\
\pm 0.025 \\
15\end{array}$ & $\begin{array}{c}0.286 \pm 0.134 \\
210\end{array}$ & $\begin{array}{c}0.404 \\
\pm 0.070 \\
225\end{array}$ & $\begin{array}{c}12.442 \\
\pm 0.345 \\
14\end{array}$ & $\begin{array}{c}0.166 \\
\pm 0.071 \\
60\end{array}$ & $\begin{array}{c}0.848 \\
\pm 0.026 \\
210\end{array}$ \\
\hline BA & - & - & - & $\begin{array}{c}0.635 \pm 0.019 \\
15\end{array}$ & $\begin{array}{c}0.970 \\
\pm 0.023 \\
210\end{array}$ & $\begin{array}{c}0.608 \\
\pm 0.064 \\
225\end{array}$ & $\begin{array}{c}0.490 \\
\pm 0.017 \\
15\end{array}$ & $\begin{array}{c}0.532 \pm 0.070 \\
210\end{array}$ & $\begin{array}{c}0.591 \\
\pm 0.076 \\
225\end{array}$ & . & $x_{0}$ & $-1.0 \mathrm{cos}$ \\
\hline $\mathrm{BI}$ & - & - & - & $\begin{array}{c}0.482 \pm 0.034 \\
15\end{array}$ & $\begin{array}{c}0.719 \\
\pm 0.098 \\
210\end{array}$ & $\begin{array}{c}0.742 \\
\pm 0.054 \\
225\end{array}$ & - & - & - & - & - & - \\
\hline $\mathrm{BU}$ & $\begin{array}{c}2.239 \\
\pm 0.110 \\
15\end{array}$ & $\begin{array}{c}0.530 \\
\pm 0.064 \\
210\end{array}$ & $\begin{array}{c}0.386 \\
\pm 0.057 \\
225\end{array}$ & - & - & - & $\begin{array}{c}0.436 \\
\pm 0.017 \\
15\end{array}$ & $\begin{array}{c}0.759 \pm 0.044 \\
210\end{array}$ & $\begin{array}{c}0.586 \\
\pm 0.043 \\
225\end{array}$ & $\begin{array}{c}13.528 \\
\pm 0.281 \\
14\end{array}$ & $\begin{array}{c}0.116 \\
\pm 0.040 \\
60\end{array}$ & $\begin{array}{c}0.909 \\
\pm 0.021 \\
210\end{array}$ \\
\hline BK & - & - & - & - & - & - & $\begin{array}{c}0.490 \\
\pm 0.022 \\
15\end{array}$ & $\begin{array}{c}0.493 \pm 0.094 \\
210\end{array}$ & $\begin{array}{c}0.577 \\
\pm 0.058 \\
225\end{array}$ & $\begin{array}{c}13.132 \\
\pm 0.315 \\
15\end{array}$ & $\begin{array}{c}0.033 \\
\pm 0.021 \\
60\end{array}$ & $\begin{array}{c}0.924 \\
\pm 0.020 \\
225\end{array}$ \\
\hline CS & $\begin{array}{c}2.113 \\
\pm 0.126 \\
15\end{array}$ & $\begin{array}{c}0.233 \\
\pm 0.092 \\
210\end{array}$ & $\begin{array}{c}0.244 \\
\pm 0.065 \\
225\end{array}$ & $\begin{array}{c}0.269 \\
\pm 0.046 \\
15\end{array}$ & $\begin{array}{c}0.500 \\
\pm 0.155 \\
210\end{array}$ & $\begin{array}{c}0.383 \\
\pm 0.073 \\
225\end{array}$ & $\begin{array}{c}0.390 \\
\pm 0.024 \\
15\end{array}$ & $\begin{array}{c}0.057 \pm 0.025 \\
210\end{array}$ & $\begin{array}{c}0.128 \\
\pm 0.043 \\
225\end{array}$ & $\begin{array}{c}14.442 \\
\pm 0.330 \\
15\end{array}$ & $\begin{array}{c}0.120 \\
\pm 0.066 \\
60\end{array}$ & $\begin{array}{c}0.906 \\
\pm 0.026 \\
225\end{array}$ \\
\hline $\mathrm{DE}$ & - & - & - & - & - & - & - & - & - & $\begin{array}{c}12.406 \\
\pm 0.146 \\
15\end{array}$ & $\begin{array}{c}0.016 \\
\pm 0.016 \\
60\end{array}$ & $\begin{array}{c}0.893 \\
\pm 0.022 \\
225\end{array}$ \\
\hline ER & $\begin{array}{c}2.221 \\
\pm 0.087 \\
15\end{array}$ & $\begin{array}{c}0.553 \\
\pm 0.087 \\
210\end{array}$ & $\begin{array}{c}0.275 \\
\pm 0.041 \\
225\end{array}$ & $\begin{array}{c}0.502 \pm 0.012 \\
15\end{array}$ & $\begin{array}{c}0.856 \\
\pm 0.078 \\
210\end{array}$ & $\begin{array}{c}0.760 \\
\pm 0.038 \\
225\end{array}$ & $\begin{array}{c}0.534 \\
\pm 0.030 \\
15\end{array}$ & $\begin{array}{c}0.564 \pm 0.109 \\
210\end{array}$ & $\begin{array}{c}0.715 \\
\pm 0.043 \\
225\end{array}$ & $\begin{array}{l}15.462 \\
\pm 0.216 \\
\end{array}$ & $\begin{array}{c}0.100 \\
\pm 0.044 \\
60\end{array}$ & $\begin{array}{c}0.937 \\
\pm 0.016 \\
225\end{array}$ \\
\hline $\mathrm{ES}$ & - & - & -20 & - & - & - & - & - & -50 & $\begin{array}{c}10.919 \\
\pm 0.429 \\
14\end{array}$ & $\begin{array}{c}0.016 \\
\pm 0.016 \\
60\end{array}$ & $\begin{array}{c}0.764 \\
\pm 0.043 \\
210\end{array}$ \\
\hline
\end{tabular}




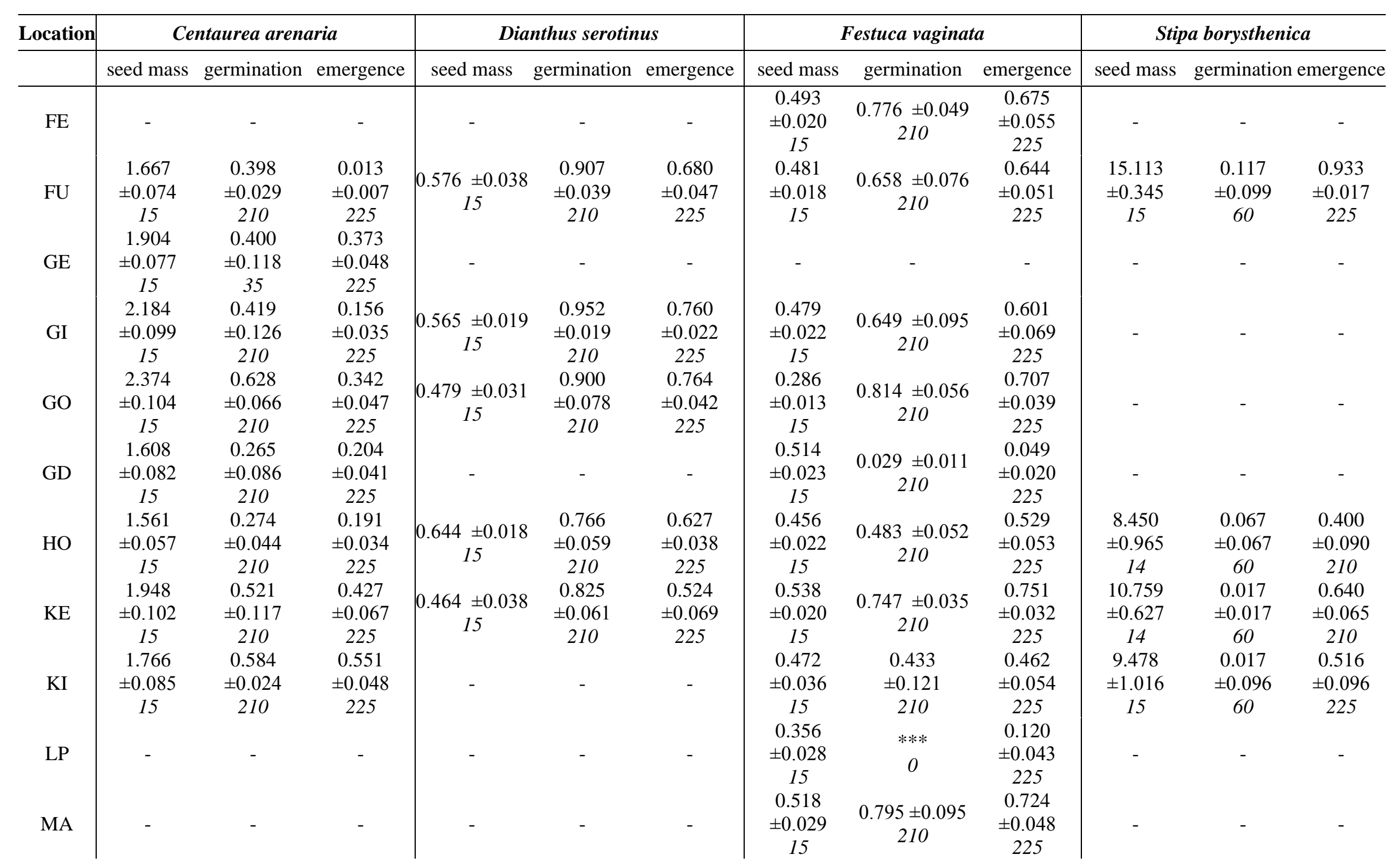




\begin{tabular}{|c|c|c|c|c|c|c|c|c|c|c|c|c|}
\hline \multirow[t]{2}{*}{ Location } & \multicolumn{3}{|c|}{ Centaurea arenaria } & \multicolumn{3}{|c|}{ Dianthus serotinus } & \multicolumn{3}{|c|}{ Festuca vaginata } & \multicolumn{3}{|c|}{ Stipa borysthenica } \\
\hline & seed mass & germination & emergence & seed mass & germination & emergence & seed mass & germination & emergence & seed mass & germinatio & emergence \\
\hline $\mathrm{MO}$ & - & - & - & - & - & - & $\begin{array}{c}0.483 \\
\pm 0.016 \\
15\end{array}$ & $\begin{array}{c}0.781 \pm 0.063 \\
210\end{array}$ & $\begin{array}{c}0.693 \\
\pm 0.037 \\
225\end{array}$ & $\begin{array}{c}12.589 \\
\pm 0.257 \\
15\end{array}$ & $\begin{array}{c}0.033 \\
\pm 0.021 \\
60\end{array}$ & $\begin{array}{c}0.848 \\
\pm 0.023 \\
225\end{array}$ \\
\hline MR & $\begin{array}{c}2.102 \\
\pm 1.936 \\
15\end{array}$ & $\begin{array}{c}0.624 \\
\pm 0.045 \\
210\end{array}$ & $\begin{array}{c}0.56 \pm 0.062 \\
225\end{array}$ & - & - & - & $\begin{array}{c}0.567 \\
\pm 0.015 \\
15\end{array}$ & $\begin{array}{c}0.838 \pm 0.037 \\
210\end{array}$ & $\begin{array}{c}0.867 \\
\pm 0.040 \\
225\end{array}$ & 10 & 80 & 220 \\
\hline NA & - & - & - & $\begin{array}{c}0.342 \pm 0.040 \\
10\end{array}$ & $\begin{array}{c}0.495 \\
\pm 0.113 \\
210\end{array}$ & $\begin{array}{c}0.347 \\
\pm 0.055 \\
150\end{array}$ & - & - & 200 & - & - & - \\
\hline $\mathrm{NE}$ & $\begin{array}{c}1.439 \\
\pm 0.071 \\
15\end{array}$ & $\begin{array}{c}0.059 \\
\pm 0.071 \\
210\end{array}$ & $\begin{array}{c}0.120 \\
\pm 0.038 \\
225\end{array}$ & $\begin{array}{c}0.458 \pm 0.047 \\
15\end{array}$ & $\begin{array}{c}0.808 \\
\pm 0.090 \\
210\end{array}$ & $\begin{array}{c}0.716 \\
\pm 0.037 \\
225\end{array}$ & - & - & - & - & - & - \\
\hline NY & - & - & - & - & - & - & $\begin{array}{c}0.445 \\
\pm 0.027 \\
15\end{array}$ & $\begin{array}{c}0.238 \\
\pm 0.1145 \\
210\end{array}$ & $\begin{array}{c}0.244 \\
\pm 0.071 \\
225\end{array}$ & - & - & - \\
\hline OF & $\begin{array}{c}1.839 \\
\pm 0.098 \\
15\end{array}$ & $\begin{array}{c}0.405 \\
\pm 0.084 \\
210\end{array}$ & $\begin{array}{c}0.489 \\
\pm 0.057 \\
225\end{array}$ & - & - & - & - & - & - & - & - & - \\
\hline OR & - & - & - & $\begin{array}{c}0.471 \pm 0.018 \\
15\end{array}$ & $\begin{array}{c}0.898 \\
\pm 0.076 \\
210\end{array}$ & $\begin{array}{c}0.764 \\
\pm 0.035 \\
225\end{array}$ & $\begin{array}{c}0.455 \\
\pm 0.028 \\
15\end{array}$ & $\begin{array}{c}0.703 \pm 0.132 \\
210\end{array}$ & $\begin{array}{c}0.711 \\
\pm 0.080 \\
225\end{array}$ & - & - & - \\
\hline PA & $\begin{array}{c}1.610 \\
\pm 0.088 \\
15\end{array}$ & $\begin{array}{c}0.110 \\
\pm 0.075 \\
210\end{array}$ & $\begin{array}{c}0.156 \\
\pm 0.055 \\
225\end{array}$ & $\begin{array}{c}0.604 \pm 0.047 \\
15\end{array}$ & $\begin{array}{c}0.87 \pm 0.058 \\
210\end{array}$ & $\begin{array}{c}0.707 \\
\pm 0.059 \\
225\end{array}$ & $\begin{array}{c}0.359 \\
\pm 0.017 \\
15\end{array}$ & $\begin{array}{c}0.210 \pm 0.109 \\
210\end{array}$ & $\begin{array}{c}0.244 \\
\pm 0.060 \\
225\end{array}$ & - & - & - \\
\hline PI & - & - & - & $\begin{array}{c}0.440 \pm 0.071 \\
15\end{array}$ & $\begin{array}{c}0.680 \\
\pm 0.104 \\
210\end{array}$ & $\begin{array}{c}0.431 \\
\pm 0.084 \\
225\end{array}$ & $\begin{array}{c}0.459 \\
\pm 0.027 \\
15\end{array}$ & $\begin{array}{c}0.702 \pm 0.053 \\
210\end{array}$ & $\begin{array}{c}0.356 \\
\pm 0.077 \\
225\end{array}$ & $\begin{array}{c}14.642 \\
\pm 0.833 \\
14\end{array}$ & $\begin{array}{l}0 \\
60\end{array}$ & $\begin{array}{c}0.636 \\
\pm 0.055 \\
210\end{array}$ \\
\hline SZ & - & - & - & - & $2 \pi 0$ & 200 & $\begin{array}{c}0.491 \\
\pm 0.038 \\
15\end{array}$ & $\begin{array}{c}0.269 \pm 0.064 \\
210\end{array}$ & $\begin{array}{c}0.204 \\
\pm 0.059 \\
225\end{array}$ & 17 & - & 210 \\
\hline TA & $\begin{array}{c}1.719 \\
\pm 0.052 \\
15\end{array}$ & $\begin{array}{c}0.211 \\
\pm 0.070 \\
210\end{array}$ & $\begin{array}{c}0.124 \\
\pm 0.036 \\
225\end{array}$ & $\begin{array}{c}0.585 \pm 0.022 \\
15\end{array}$ & $\begin{array}{c}0.914 \\
\pm 0.028 \\
210\end{array}$ & $\begin{array}{c}0.813 \\
\pm 0.042 \\
225\end{array}$ & $\begin{array}{c}0.442 \\
\pm 0.020 \\
15\end{array}$ & $\begin{array}{c}0.500 \pm 0.101 \\
210\end{array}$ & $\begin{array}{c}0.307 \\
\pm 0.059 \\
225\end{array}$ & - & - & - \\
\hline
\end{tabular}




\begin{tabular}{|c|c|c|c|c|c|c|c|c|c|c|c|c|}
\hline \multirow[t]{2}{*}{ Location } & \multicolumn{3}{|c|}{ Centaurea arenaria } & \multicolumn{3}{|c|}{ Dianthus serotinus } & \multicolumn{3}{|c|}{ Festuca vaginata } & \multicolumn{3}{|c|}{ Stipa borysthenica } \\
\hline & seed mass & germination & emergence & seed mass & germination & emergence & seed mass & germination & emergence & seed mass & germinatio & mergence \\
\hline $\mathrm{TZ}$ & $\begin{array}{c}2.0771 \\
\pm 0.090 \\
15\end{array}$ & $\begin{array}{c}0.562 \\
\pm 0.071 \\
210\end{array}$ & $\begin{array}{c}0.471 \\
\pm 0.038 \\
225\end{array}$ & - & - & - & $\begin{array}{c}0.503 \\
\pm 0.018 \\
15\end{array}$ & $\begin{array}{c}0.600 \pm 0.121 \\
210\end{array}$ & $\begin{array}{c}0.573 \\
\pm 0.049 \\
225\end{array}$ & - & - & - \\
\hline $\mathrm{TE}$ & $\begin{array}{c}1.642 \\
\pm 0.070 \\
15\end{array}$ & $\begin{array}{c}0.123 \\
\pm 0.022 \\
210\end{array}$ & $\begin{array}{c}0.169 \\
\pm 0.022 \\
225\end{array}$ & - & - & - & $\begin{array}{c}0.483 \\
\pm 0.017 \\
15\end{array}$ & $\begin{array}{c}0.685 \pm 0.098 \\
210\end{array}$ & $\begin{array}{c}0.649 \\
\pm 0.050 \\
225\end{array}$ & $\begin{array}{c}14.655 \\
\pm 0.337 \\
15\end{array}$ & $\begin{array}{c}0.183 \\
\pm 0.060 \\
60\end{array}$ & $\begin{array}{c}0.986 \\
\pm 0.007 \\
225\end{array}$ \\
\hline $\mathrm{ZS}$ & - & - & - & - & - & - & $\begin{array}{c}0.426 \\
\pm 0.023 \\
15\end{array}$ & $\begin{array}{c}0.731 \pm 0.079 \\
210\end{array}$ & $\begin{array}{c}0.489 \\
\pm 0.028 \\
225 \\
\end{array}$ & - & - & - \\
\hline
\end{tabular}

